\title{
Ownership Structure and Corporate Performance: Evidence from Bangladesh
}

\author{
Omar Al Farooque, ${ }^{a^{*}}$ Tony van Zijl, ${ }^{\mathrm{b}}$ \\ Keitha Dunstan ${ }^{\mathrm{c}}$ and AKM Waresul Karim ${ }^{\mathrm{d}}$
}

${ }^{a}$ University of New England

${ }^{b, c, d}$ Victoria University of Wellington

\begin{abstract}
This paper models the corporate ownership and performance relationship in Bangladesh listed firms using a simultaneous equations approach. Consistent with contemporary literature a "reverse-way" causality relationship between the two is documented. Using an unbalanced pooled sample of 660 firm-years, our results suggest that ownership does not have a significant impact on performance (Tobin's Q or ROA). However, performance does appear to have a significant negative impact on ownership. With few exceptions, other governance and control variables appear to have significant effects on both performance and ownership. These results imply that despite significant governance differences between Bangladesh and developed market economies there are strong similarities in "internal governance mechanisms" and the implications of agency theory.
\end{abstract}

JEL Classification: G32, G34

Keywords: Emerging markets, board ownership, financial performance, endogeneity, reverse-way causality

\section{Introduction}

The nature of the relationship between ownership and financial performance is a key issue for governance. Some corporate governance studies support the existence of a linear or monotonic relationship between ownership and performance (Berle and Means, 1932; Jensen and Meckling, 1976; Lichtenberg and Pushner, 1994; Mehran, 1995),

\footnotetext{
* Corresponding author: Omar Al Farooque, Lecturer, School of Business, Economics and Public Policy, University of New England, Armidale NSW2351, Australia. Tel: +61 267732201 Fax: +61 267733148 E-mail: ofarooque@une.edu.au,omaral.farooque@gmail.com.
} 
while others support a non-linear or non-monotonic relationship between them (Morck et al., 1988; McConnell and Servaes, 1990 and 1995; Chen et al., 1993; Short and Keasey, 1999). Both sets of studies assume a uni-directional ${ }^{1}$ relationship, based on the assumption that ownership is exogenous. This notion was questioned by Demsetz (1983) and Demsetz and Lehn (1985), who argue that ownership structure is endogenously related to firm performance with no direct relationship expected between the two. The debate, however, has been broadened by some of the more recent empirical studies. These studies present evidence of either a reverse-way ${ }^{2}$ or a bi-directional ${ }^{3}$ relationship between them using a simultaneous equations approach to model endogeneity (Chung and Pruitt, 1996; Loderer and Martin, 1997; Cho, 1998; Bohren and Odegaard, 2001; Demsetz and Villalonga, 2001).

Most of this research has been carried out for developed market countries, most notably the United States. Only a few of the studies have considered emerging market economies, with none focusing on Bangladesh. There exist huge institutional differences, including the mechanisms of corporate governance, between Bangladesh and the developed economies. However, it is not known whether existing differences in institutional, regulatory and corporate governance practices also translate into differences in the relationship between ownership and firm performance. This study seeks to answer precisely this question by using a simultaneous equations framework to study the nature of the relationship between ownership as indicated by board ownership (the percentage shareholding held by board members) and financial performance, as measured by Tobin's Q and ROA, for Bangladesh listed firms. The remainder of this paper is structured as follows. Section 2 briefly examines the literature that applies a simultaneous equations approach to investigate the ownership-performance relationship. Section 3 compares the governance mechanisms applied in Bangladesh with those of the developed market economies. Section 4 details the research methodology and data while Section 5 describes the results of empirical testing. Finally, Section 6 provides the conclusions of the paper.

\section{Literature Review}

Most research on the relationship between ownership and financial performance is rooted in an agency framework. It is argued that the separation of ownership from control for a corporate firm creates an agency problem that results in conflicts between shareholders and managers (Jensen and Meckling, 1976; Shleifer and Vishny, 1997). The interests of other investors can generally be protected through contractual arrangements between the company and concerned stakeholders, leaving shareholders as the residual claimants whose interests can adequately be protected only through the institutions of corporate governance (Shleifer and Vishny, 1997). Since ownership structure remains the basis for exercising power and control over corporate entities under conditions of

\footnotetext{
${ }^{1}$ Causality of relationship runs from ownership structure to financial performance.

${ }^{2}$ Causality of relationship runs from financial performance to ownership structure.

${ }^{3}$ Causality of relationship runs simultaneously in both directions i.e. from ownership to performance and from performance to ownership.
} 
market imperfections and/or incomplete nature of contracts, the problem of agency costs needs to be addressed according to the ownership structure of the firm to ensure efficient financial performance. For a publicly traded firm with widely dispersed shareholdings, the challenge for shareholders is to control the behavior of dominating managers and/ or of the board. The challenge for a closely held firm with a controlling shareholder and a small number of outside minority shareholders or a widely held firm dominated by a controlling shareholder is how outside shareholders can prevent the controlling shareholder from extracting excess benefits to the detriment of minority shareholders (World Bank, 1999). Therefore, to ensure optimum performance and minimize agency costs, ownership structure is considered to be one of the core governance mechanisms along with others such as, debt structure, board structure, incentive-based compensation structure, dividend structure, and external auditing.

In the literature, there are alternative views on the relationship between ownership and performance. One approach assumes an exogenous optimal ownership structure that combines with other governance mechanisms to collectively maximize firm value. The other approach assumes that firms choose a combination of ownership structure and other governance mechanisms to maximize performance while recognizing that ownership is itself affected by performance, that is, it is endogenous. Accordingly, empirical studies addressing the relationship between ownership structure and performance provide two opposite and contradictory views on the role of ownership.

Assuming ownership is exogenous and applying ordinary least squares, one group of studies provides evidence of either a linear or a non-linear relationship between ownership and performance. The other group assumes ownership and performance to be endogenous and applies two-stage least-squares (2-SLS) or three-stage least-squares (3-SLS) to a set of simultaneous equations and finds either no evidence of a systematic relationship between the variables or a reverse causality between them. A reverse causality finding implies that performance determines ownership structure, and not the other way around. The former group of studies supports either the interest alignment hypothesis (Berle and Means, 1932; Jensen and Meckling, 1976; Hart and Holmstrom, 1987; Morck et al., 1988) or the entrenchment hypothesis (Fama and Jensen, 1983 a \& b; Morck et al., 1988) or both. The latter group supports the natural selection hypothesis (Demsetz, 1983; Demsetz and Lehn, 1985; Kole and Lehn, 1997) or the mutual neutralization hypothesis (Jensen, 1986). Some of the studies that identify reverse causality argue in favor of the reward hypothesis (Kole, 1996), the insider-reward hypothesis (Cho, 1998) and the insider-investment hypothesis (Loderer and Martin, 1997).

In the empirical literature, Loderer and Martin (1997) consider Tobin's Q and managerial ownership as endogenous in a simultaneous equations framework and use data on acquisitions to investigate whether executive stock ownership boosts the performance of the bidding firms. Using 2-SLS regression, they find no evidence that larger managerial ownership boosts performance. In contrast, performance appears to have a negative effect on executive stockholdings. Cho (1998) confirms a reverseway causality relationship between ownership and performance. He focuses on the hypothesis that insider ownership affects investment (capital expenditure, R\&D), which in turn affects corporate performance (Tobin's Q). Using simultaneous equations to 
model endogeneity, he uses cross-sectional 2-SLS regressions and finds that investment positively affects corporate value, which in turn affects insider ownership. Demsetz and Villalonga (2001) also address endogeneity concerns about the performance-ownership relationship by using a simultaneous equations model. Their 2-SLS estimates show no statistical relationship between managerial ownership or top 5 shareholders' ownership and performance. Rather, they find a significant negative influence of performance (Tobin's Q or ROA) on managerial ownership or ownership of top 5 shareholders. That is, similar to Loderer and Martin (1997), management seems to hold fewer shares when a firm is doing well. Comparing the degree of endogeneity of management shareholdings and top 5 shareholders' shareholdings, Demsetz and Villalonga's (2001) model shows that Tobin's $Q$ has a stronger effect on managerial ownership than that of top 5 shareholders' shareholdings.

Bohren and Odegaard (2001) conduct a similar study using simultaneous equations on Norwegian data. Consistent with the findings of several prior studies, they present evidence that performance drives insider ownership but not vice versa. Fernandez and Gomez (2002) also estimate simultaneous equations using a pooled sample of Spanish firms. Their findings show that managerial ownership does not appear to influence firm performance (either as market-to-book value ratio or ROA). Similarly, Agrawal and Knoeber (1996) and Firth et al. (2002) construct a complex system of simultaneous equations for US and Chinese firms respectively. Both studies find no evidence of ownership influencing firm performance.

\section{Bangladesh Institutional Setting}

Bangladesh is an emerging economy. Corporate governance systems here are arguably less evolved than those in developed countries such as the Anglo-American countries, Germany, or Japan. Emerging markets as a whole differ substantially from developed countries in their institutional, regulatory and legal environments (Prowse, 1999). The Mckinsey Emerging Market Investor Opinion Survey (2001) highlights that the "emerging market corporate governance model" is markedly different from that prevailing in the US, UK and other English-speaking countries in that the emerging market model is typically characterized by the control model of having concentrated ownership, insider boards, limited disclosure, inadequate minority shareholder protection, and a limited takeover market. In contrast, the typical features of the developed markets model include dispersed ownership, non-executive majority boards, high disclosure, shareholder equality, institutional investment, and an active takeover market. Considering the above distinction, Bangladesh comfortably fits the emerging market model.

The development of corporate governance mechanisms (institutional, regulatory or legal) depends on the political, cultural and historical characteristics of a country (Prowse, 1999). Bangladesh carries the legacy of nearly two hundred years of British colonial rule. This has had a twin impact as far as corporate governance is concerned. On the one hand, it allowed Bangladesh to inherit an English-style institutional and regulatory framework in the form of a Companies Act (originally enacted in 1913 in the British 
Parliament), Westminster-style parliamentary democracy, a judiciary independent of the legislature and the executive wings of the government, and a highly powerful and insensitive bureaucracy. On the other hand, the prolonged economic exploitation and political domination coupled with the creation of a crony elite subservient to the expatriate rulers contributed to institutionalizing corruption in the bureaucracy, creating only a limited pool of entrepreneurs, and inhibiting development of a broadbased capital market. The 23 years of internal colonization during the Pakistan period also saw a continuation of political suppression and economic negligence. The chronic shortage of natural and human resources compounded by frequent natural disasters did not allow the country, with arguably the highest population density ${ }^{4}$ in the world, to build capital market institutions or carry out urgent institutional reforms even three decades after independence. Although Bangladesh inherited "English common-law", it has weak, relatively unsophisticated, legal and regulatory frameworks and enforcement mechanisms to protect investor rights. The courts in Bangladesh are poorly equipped to oversee corporate affairs, confirming La Porta et al's (1998 and 1999) observation on the judiciary in emerging economies. In Bangladesh, problems relate to delays and inefficient, distorted, or differential treatment in enforcing existing laws and securing outcomes. Lack of transparency and accountability are not uncommon in the corporate sector, and are similar to those in other emerging East and South East Asian countries (Prowse, 1999). Furthermore, despite having a market-based system similar to AngloAmerican firms, Bangladesh lacks an active market for corporate control, strong incentive contracts for management, and outside directors, etc. A further problem lies in the widely recognized presence of market anomalies and malpractices (e.g. unavailability of information to investors, insider control and collusion to manipulate stock prices in the market).

As a natural outcome of the above conditions prevailing in the corporate sector, the Bangladesh market comprises of mainly small and medium-sized firms with highly concentrated ownership. Ownership has become the predominant corporate governance mechanism, similar to the control model found in Germany and Japan. But, unlike the institutional majority owners of Japanese and German firms, concentrated individual or founder-family owners dominate private listed firms in Bangladesh. Therefore, institutional activism occurs less in Bangladesh than in the JapaneseGerman systems. However, similar to the Japanese and German firms, most listed firms in Bangladesh rely heavily on either bank or public (i.e. government) funds and less on direct market sources for raising external finance. Nevertheless, Bangladesh firms emphasize shareholders' interests, similar to Anglo-American firms. But, unlike the Anglo-American countries, the market for takeovers is weak and underdeveloped in Bangladesh. Therefore, the institutional setting for ownership structure in Bangladesh has unique features, an appreciation of which is important to understanding the governance mechanisms and processes that have evolved in Bangladesh.

Corporate governance systems in Bangladesh are firmly based on family ownership and insider-domination. In most firms major shareholders are family groups and in a few firms government is the major shareholder. Other shareholders in the firm's ownership

\footnotetext{
${ }^{4}$ At the time of independence in 1971, the country's population was only 70 million. In 2007, its population was estimated to be 150 million. The size of Bangladesh is about half that of the UK.
} 
structure are financial institutions and other corporate blockholders, domestic individuals and foreign investors. The ownership structure in Bangladesh is not of pyramid type and holding companies are virtually non-existent. Firms are owned independently by family owners and other shareholders. Controlling families dominate the boards in most companies, filling positions of executive directors, and CEOs/Chairpersons. Similarly, institutional, corporate and individual blockholders in Bangladesh typically sit on the boards as non-executive directors. Only rarely do blockholders sit on boards. This type of organizational structure creates opportunities for controlling shareholders to expropriate wealth from other shareholders (Shleifer and Vishny, 1997). Given these institutional features, agency conflict between large owners and other shareholders (Shleifer and Vishny, 1986) rather than between professional managers and shareholders (Jensen and Meckling, 1976) is likely to be prominent in Bangladesh corporate firms. Thus, family-based board ownership has its costs in the form of potential expropriation of small shareholders' wealth in the firm by owners/board members representing founding families. However, some other ownership types, in particular, institutional shareholders, are capable of offsetting such costs of board ownership through their large shareholdings and ability to monitor managerial behavior.

\section{Methodology, Hypothesis and Data}

\subsection{Methodology and Hypothesis}

The null hypothesis is tested:

Ho: There is no relationship between ownership and firm performance, in either direction.

However, if Bangladesh firms conform to the apparent experience of firms in developed economies then it would be expected that ownership would have no impact on performance but that performance does impact on ownership. We proxy ownership by the percentage of the shares held by board members - board ownership, and measure performance by both Tobin's Q and Return on Assets (ROA).

The relationship between ownership and performance is modeled as a set of simultaneous equations. The equation system consists of two equations with ownership and performance as the endogenous variables and includes explanatory variables for alternative governance mechanisms and selected firm-level characteristics. Several explanatory variables are common to the board ownership and performance equations. The variables included in the model are those that have commonly been included in the prior empirical studies in this field of research. The definitions and expected signs of the variables included in the equations are presented in Figure 1 in Appendix 1. The regression models have been tested for possible multi-collinearity, auto-correlation, heteroskedasticity and stability. No evidence of the above-mentioned problems was found. The simultaneous equations are: 
$L O G-T O B I N ' S Q_{i}$ or $R O A_{i}=\beta_{0}+\beta_{1}$ BD-SHARE $+\beta_{2}$ INST-SHARE $E_{i}+\beta_{3}\left(I N S T-S H A R E_{i}\right)^{2}$ $+\beta_{4}$ NON-EXE-DIR-Ratio ${ }_{i}+\beta_{5} B D-S A L_{i}\left(\right.$ Spline-1) $+\beta_{6} B D-S A L_{i}($ Spline -2$)+\beta_{7} B D-$ $S A L_{i}\left(\right.$ Spline-3) $+\beta_{8}$ CEO-DUM $M_{i}+\beta_{9}$ CEO-CHAIR-DUAL-DUM ${ }_{i}+\beta_{10}$ CEO-TENURE $+\beta_{11}$ BIG-4 AUDIT-DUM ${ }_{i}+\beta_{12}$ DPS $_{i}+\beta_{13}$ DEBT-Ratio $_{i}+\beta_{14}$ LOG-SALES $_{i}+\beta_{15}$ INVEST-Ratio ${ }_{i}+\beta_{16}$ ADVER-Ratio ${ }_{i}+\beta_{17}$ EARN-VOLATILE $E_{i}+\varepsilon_{i}$

Board Ownership Equation

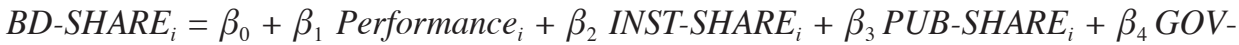

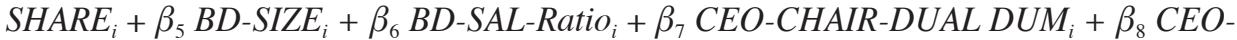
TENURE $_{i}+\beta_{9}$ FIRM-AGE $_{i}+\beta_{10}$ DEBT-Ratio $_{i}+\beta_{11}$ LOG-ASSETS $_{i}+\beta_{12}$ INVEST-Ratio $_{i}$ $+\beta_{13}$ PROFIT-VOLATILE ${ }_{i}+\beta_{14}$ LIQUIDITY-Ratio $_{i}+\varepsilon_{i}$

\subsubsection{Financial performance equation}

Two alternative measures of firm performance are employed in this study; Tobin's $\mathrm{Q}$ and Return on Assets (ROA). Tobin's Q is used as a forward-looking market/hybrid measure of financial performance, whereas $R O A$ is a backward-looking accounting measure of performance. ROA is the aggregate rate of return on capital employed - both equity and debt capital - and is measured by the ratio of earning before interest and taxes (EBIT) to book value of total assets employed. Tobin's Q reflects firm performance as an indicator of the value of a firm as a going concern relative to the sum of the replacement costs of individual assets employed by the firm. Lindenberg and Ross (1981) discuss the theoretical Tobin's Q. In this study, measurement problems did not allow the adoption of the theoretical Tobin's Q. As an alternative, an approximate measure of Q similar to Chung and Pruitt (1994) is adopted for this study:

\section{Simple or Approximate $\mathrm{Q}=(M V E+D E B T) / B V T A$}

Here, $M V E$ is the market value of the firm's equity, $D E B T$ is the book value of the firm's total debt and BVTA is the book value of total assets of the firm. This simple Q-value deviates from the theoretical Q in its use of the book value of total assets instead of their replacement cost and in the use of the book value of debt. Fernandez and Gomez (2002) indicate that the results of the empirical work are not likely to be sensitive to use of the Chung and Pruitt's (1994) approximation. The measure used for Tobin's Q is log-transformed to ensure its distribution is near normal and to reduce the impact of outliers.

$B D$-SHARE (board ownership) is the primary variable of interest in Equation 1 and it is the other endogenous variable in the simultaneous equations system. INSTSHARE and (INST-SHARE) ${ }^{2}$ denote the shareholdings of financial institutions and its squared value, respectively. A U-shaped non-linear relation is expected for this variable. The NON-EXE-DIR-Ratio is the ratio of non-executive directors (outsiders) to total number of directors in the board. A positive relation is expected, assuming that nonexecutive directors exert some influence using their strength of "independence" from 
top management and their interests are aligned with minority shareholders. Anticipating a non-linear relation, $B D-S A L$ (board salary) is composed of three splines or piecewise variables ranging from a board salary of Tk. 00 to 0.15 million, Tk. 0.15 to 0.75 million and over Tk. 0.75 million. CEO-DUM (owner/sponsor-CEO) is a dummy variable to test the influence of "entrepreneurial talent" equal to 1 if the owner director acts as the CEO and 0 otherwise. CEO-CHAIR-DUAL-DUM (CEO-chairman duality) is also a dummy variable equal to 1 if the CEO also acts as the chairman of the board and 0 otherwise. CEO-TENURE is the human capital employed by the CEO into the firm in terms of their length of service in the firm. These three variables are related to the CEO who often comes from a dominant owner family or is the founder of the firm. In line with agency conflict between controlling and minority shareholders, an inverse relationship between these three variables and firm performance is expected.

In addition to the above governance variables, certain firm level control variables are also included. To control for a firm's accounting and auditing quality and important financial policy decisions, the variable BIG-4 AUDIT-DUM (Big-4 affiliated audit firm) is a dummy variable denoted as 1 if the firm's audit firm is affiliated with a Big-4 audit firm and 0 otherwise. A positive relation is anticipated between Big-4 affiliated audit firm and firm performance. For DPS (dividend per share) it is assumed that there is a positive association with performance as it is interpreted as a signal of performance to minority shareholders. DEBT-Ratio is denoted as the percentage of total debt to total assets of the firm. Agency theory predicts debt as a potential tool for mitigating agency conflicts through additional monitoring. However, the pecking order theory assumes a negative association between debt and firm performance. A negative relation is expected between debt and performance as the pecking order theory is likely to be more applicable in Bangladesh. Finally, several control variables are included that may have a significant impact on performance. LOG-SALES is employed to control for differences in firm size. INVEST-Ratio and ADVER-Ratio denote, respectively, capital and advertising expenditure scaled by total assets. Both ratios are discretionary expenditures - a proxy for the future growth of the firm $^{5}$ and positive associations are expected between these variables and performance. EARN-VOLATILE is the firm-specific business risk measured by the standard deviation of operating income scaled by sales. A negative performance relation is expected for a noisier environment and instability in the firm's environment.

\subsubsection{Board ownership equation}

The endogenous dependent variable, BD-SHARE, is defined as the percentage of common stock held by the members of the board. ${ }^{6}$ With respect to explanatory variables, the first variable in Equation 2 is the other endogenous variable, measuring financial performance, Tobin's Q or ROA. INST-SHARE denotes financial institutions' shareholdings, while GOV-SHARE and PUB-SHARE represent government and

\footnotetext{
${ }^{5}$ Empirical studies use R\&D as a discretionary expenditure. R\&D expenditure cannot be used due to its unavailability. In any case, R\&D expenditure in Bangladesh is undertaken only by a few multinationals and joint-venture firms.

${ }^{6}$ Preferred stock is not available for the sample periods and stock-options are not issued by Bangladesh listed firms.
} 
minority shareholdings respectively and are viewed as substitute mechanisms to board ownership. A negative association of these variables with board ownership is predicted. $B D$-SIZE is the total number of directors and a positive association is expected between board ownership and board size. The BD-SAL-Ratio is expected to have a negative association with board ownership for its complementary effect on the firm. $C E O$ CHAIR-DUAL DUM and CEO-TENURE variables are expected to have a positive relationship with board ownership. A positive association is predicted between $D E B T$ Ratio and board ownership and INVEST-Ratio and board ownership, and a negative association between firm age and board ownership and LOG-ASSETS (firm size) and board ownership. PROFIT-VOLATILE is the business risk measured by the standard deviation of return on equity. A positive effect of this variable with board ownership is expected. LIQUIDITY-Ratio is the liquidity position of the firm measured by cash flow to total assets and a positive effect on board ownership is anticipated.

\subsection{Data}

The study is based on the total population of listed firms in Bangladesh for the period 1995 to 2001. The main performance data was obtained from DataStream while other firm level data were manually collected from individual company annual reports for the respective years. Price data of firms not available in the DataStream were collected from the DSE Monthly Reviews, a monthly bulletin published by the Dhaka Stock Exchange. Firms ceasing to trade during the period, having negative equity, or having data missing for any variable used in the models were excluded from the study. All firms who survived the above screening for the whole study period were included in the analysis. The number of firms included in the study thus varied across the study period and resulted in an unbalanced pooled sample of 660 firm-years over the period from 1995 to 2001 inclusive.

Table 1 in Appendix 2 reports descriptive statistics for the variables used in the model. The sample has a mean (median) Tobin's Q of 1.157 (0.989), which is higher than or close to 1 indicating favorable average growth prospects for the sample firms. The mean (median) ROA is relatively low at 0.081 (0.08). Average board shareholding of 0.387 with a median of 0.477 is higher than that found in developed economies. The mean (median) institutional shareholding is $18 \%$ (17\%), mean Government shareholding is below $3 \%$ while mean minority shareholding is approximately $30 \%$. Similar to other jurisdictions, the average board size is 8 . Non-executive directors constitute nearly twothirds of the board. Average board salary including that of the CEO is close to Tk.1 million, equivalent to approximately $4 \%$ of operating expenses. About $78 \%$ of CEOs are also shareholders of the firm, either as founder shareholders or as descendants of founding families. Average CEO tenure is between 9 and 10 years, which is high given that the average firm age is between 14 and 15 years. Approximately $40 \%$ of the sample has a Chairman who is also the CEO. Nearly one-third of the firms have a Big-4 affiliated audit firm. The mean debt ratio of the sample firms is close to $60 \%$ while capital expenditure is close to 5\% of total assets. Advertising expenditure is low. The mean liquidity (cash flow) ratio is also low, ranging between $6 \%$ and $7 \%$ of total assets. 


\section{Results}

Tables 3 and 4 in Appendix 2 present the results of estimating the model using 2-SLS. For comparative purposes, OLS estimates for the individual equations are also presented. It should be noted that, consistent with prior research, the relationship between board ownership and performance found under OLS is not found by 2-SLS estimation of the simultaneous equation model. Deviation from OLS results confirms the need to allow for endogeneity of the variables. The key results of the study, extracted from Tables 3 and 4 in Appendix 2, are shown in Table 2 below:

Table 2

Highlights of Key Variables

(a) Determinants of Tobin's Q and Board Ownership

\begin{tabular}{lllll}
\hline Variables & $\begin{array}{c}\text { Log Tobin's } \\
\mathbf{Q} \\
(\mathbf{O L S})\end{array}$ & $\begin{array}{c}\text { Log Tobin's } \\
\mathbf{Q} \\
(\mathbf{2 S L S})\end{array}$ & $\begin{array}{c}\text { Board } \\
\text { Ownership } \\
(\mathbf{O L S})\end{array}$ & $\begin{array}{c}\text { Board } \\
\text { Ownership } \\
(\mathbf{2 S L S})\end{array}$ \\
\hline \multirow{2}{*}{ CONSTANT } & -0.055 & -0.076 & 0.724 & 0.702 \\
& $(-1.055)$ & $(-1.367)$ & $(17.418)^{* * *}$ & $(13.010)^{* * *}$ \\
BD-SHARE & -0.116 & -0.054 & & \\
& $(-2.722)^{* * *}$ & $(-0.796)$ & & \\
LOG TOBIN'S-Q & & & -0.172 & -0.846 \\
& & & $(-5.306)^{* * *}$ & $(-6.538)^{* * *}$ \\
\hline
\end{tabular}

(b) Determinants of ROA and Board Ownership

\begin{tabular}{lllll}
\hline Variables & $\begin{array}{l}\text { ROA } \\
(\text { OLS) }\end{array}$ & $\begin{array}{l}\text { ROA } \\
(\mathbf{2 S L S})\end{array}$ & $\begin{array}{c}\text { Board } \\
\text { Ownership } \\
\text { (OLS) }\end{array}$ & $\begin{array}{c}\text { Board } \\
\text { Ownership } \\
\text { (2SLS) }\end{array}$ \\
\hline CONSTANT & 0.019 & 0.013 & 0.735 & 0.758 \\
BD-SHARE & $(1.028)$ & $(0.682)$ & $(17.242)^{* * *}$ & $(16.930)^{* * *}$ \\
ROA & 0.011 & 0.029 & & \\
& $(0.733)$ & $(1.213)$ & & -1.040 \\
& & & -0.168 & $(-2.720)^{* * *}$ \\
\hline
\end{tabular}

\subsection{Reverse Causality Relationship between Board Ownership and Performance}

Table 2 (a) provides the 2-SLS estimates for Tobin's Q and board ownership. In the 2-SLS performance equation, board ownership is not found to have a significant impact on Tobin's Q. However, in the OLS regression, board ownership has highly significant negative association with Tobin's Q. In the 2-SLS ownership equation, Tobin's Q has a statistically significant negative impact on board ownership. A significant negative impact of Tobin's Q on board ownership is also found when the determinants of board 
ownership are tested by $O L S$ regression. This provides evidence of endogeneity of board ownership showing reverse causality, that is, firm performance determines the level of board ownership rather than the other way around. Table 2 (b) reports the results for the same 2-SLS models with ROA as the measure of firm performance. In this case, both $O L S$ and 2-SLS fail to show a significant impact of board ownership on performance; however, 2-SLS (alone) shows that performance has a significant negative impact on board ownership.

The reverse causality with a negative sign found in this study is fully consistent with Loderer and Martin (1997) and Demsetz and Villalonga (2001). However, Cho (1998), and Bohren and Odegaard (2001) also found reverse causality but with a positive sign (as opposed to a negative sign found in the present study). As the direction of causality runs from performance to board ownership, the present study predicts a decrease in board ownership when firms are performing well and vice versa. This occurs as board members sell shares during good times (i.e. at high $\mathrm{Q}$ ratios or $R O A$ ) expecting good performance to be followed by poorer performance. This could also arise if directors liquidate part of their stockholdings to make capital gains for having their human capital more firm-specific; or due to the presence of monitoring by creditors (Loderer and Martin, 1997; Demsetz and Villalonga, 2001). This negative relationship also rejects the possibility that managerial ownership is higher when costs of shareholders' monitoring are higher in firms with greater investment opportunities (Smith and Watts, 1992).

\subsection{Non-linear Relationship of Institutional Ownership with Performance}

The 2-SLS regression denotes a U-shaped non-linear relationship (quadratic) between $\log$ of Tobin's $\mathrm{Q} / R O A$ ) and percentage of institutional shareholding. The turning points are $29.83 \%$, and $13.16 \%$ for Tobin's $\mathrm{Q}$ and $R O A$ respectively (Tables 3 and 4). The above turning points suggest that the institutions start monitoring the firm once they reach substantial stakes in it. While the mean (median) shareholding by institutions is approximately $18 \%(17 \%)$, they do not appear to actively monitor managerial behavior until their ownership reaches $30 \%$ (for Tobin's Q) or 13\% (for ROA) of the firm's total outstanding equity. On the other hand, the relationship between board ownership and institutional shareholding is significantly negative as indicated in 2-SLS regressions (Tables 3 and 4). It tells a story of ownership mechanisms in Bangladesh listed firms: as firm performance improves, board ownership goes down and institutional investors increase their stake by purchasing most of the shares offloaded by the directors. This happens as part of the total incentive effect that exists within the corporate structure and results in closer monitoring by institutional investors to pursue and maintain better firm performance. 


\subsection{Relationship of Other Governance and Control Variables with Performance}

The 3 piecewise (or spline) variables for board salary in the 2-SLS regression estimates presented in Tables 3 and 4 (Appendix 2), show a significant non-linear relationship with performance. In the log Tobin's Q model it appears to have a positive effect when salary range is up to Tk. 0.15 million (US\$2,500), a negative effect in salary range of Tk. 0.15 million to Tk. 0.75 million (US\$2,500 to $\$ 12,500$ ) and finally, a positive effect for board salary over Tk. 0.75 million (US\$12,500). The ROA model presents a U-shaped non-linear relationship (quadratic), slightly different from that of the Tobin's Q model with respect to the first spline. The above results suggest some sort of incentive alignment effect of board salary on performance at different levels of board salary. On the other hand, the proportion of non-executive directors in the board (the ratio of non-executive directors to all directors) shows no significant relationship with performance in either the Tobin's Q or the ROA model. This implies that the number of non-executive directors in the board is irrelevant in influencing firm value in Bangladesh listed firms. Due to the strong presence of founder CEOs or family dominance, it is not surprising that board members are not generally effective in Bangladesh.

With respect to CEO related variables, both Tobin's $\mathrm{Q}$ and $R O A$ show similar findings in 2-SLS estimates. Contrary to our expectations, the CEO dummy is significantly positive in both the performance models (Tobin's $\mathrm{Q}$ and ROA). This indicates that CEOs might have owner-specific attributes (entrepreneurial ability or talent) that contribute in enhancing firm value. Besides, some family representative CEOs are keen to build or protect family reputation by improving firm performance. Furthermore, as expected, longer CEO tenure appears to be value destructive due to an entrenchment effect or more reliance on CEO human capital rather than incentive alignment. Also the coefficients of CEO-chair duality dummy are not significant in either performance model.

The 2-SLS regression estimates indicate that Big-4 affiliated audit firm and debt ratio have significant positive relationships with Tobin's Q, while no significant relationship with $R O A$. Given the underdeveloped accounting and auditing practice in corporate firms in Bangladesh, a positive performance effect implies that the market values the quality of accounting and auditing provided by the Big-4 affiliated audit firms. The positive sign of the co-efficient of debt in the Tobin's Q model is contrary to our expectations. A negative performance effect of debt was expected, in line with pecking order theory. However, the results are consistent with the prediction of agency theory for the role of debt in mitigating agency conflicts. Dividend per share (DPS) shows a significantly positive relationship with performance for both Tobin's $\mathrm{Q}$ and ROA. In Bangladesh, dividend payment appears to be regarded as a measure of firm performance and is perceived by general investors and regulators to be a signal of better governance and/or a high quality firm. Small investors are willing to pay higher prices for firms that pay regular dividend.

Regarding control variables, the 2-SLS regression results show that firm size (measured by log sales) has a significantly positive effect on $R O A$ but no effect on Tobin's Q, which is puzzling. One possible explanation is that high sales volume may lead to an increase in $R O A$ in general. The two discretionary expenditures, investment 
and advertising, show significant positive relationships with Tobin's Q. The positive performance effects of both variables on log Tobin's Q indicate that growing firms show higher performance. However, investment expenditure reveals no significant relationship with $R O A$, while advertising expenditure indicates a positive performance effect. Finally, earning volatility of the firm shows no explanatory power with Tobin's Q, but significant negative performance effect on ROA. Although high sales volume leads to an increase in $R O A$ of the firm, higher business risk may endanger firm performance.

\subsection{Relationship of Governance and Control Variables with Board Ownership}

Considering the 2-SLS regression estimates of the board ownership equation, it is observed that institutional, public and government shareholdings have significantly negative influences on board ownership with both performance measures. Furthermore, as expected, board size, CEO tenure and CEO-chair duality have significantly positive relationships with board ownership while firm age has a significantly negative relationship. Board salary ratio has a significantly negative effect on board ownership with $R O A$ as predicted but not with Tobin's $\mathrm{Q}$. The debt ratio has a significantly positive effect on board ownership with both Tobin's $\mathrm{Q}$ and $R O A$ as per our expectations. As for the control variables, $\log$ assets shows significantly negative relationships with board ownership in both performance models as expected. On the other hand, the liquidity ratio exhibits a significantly positive relationship with board ownership with both Tobin's $\mathrm{Q}$ and ROA. Contrary to our expectations, the investment ratio shows a significantly negative relationship with board ownership with $R O A$ but no relationship with Tobin's Q model. Finally, profit volatility has a significantly positive relationship with board ownership with Tobin's Q, as predicted, but not with ROA.

\subsection{Suitability of the 2-SLS Regression Model}

With regard to the explanatory power of each of the 2-SLS models in Tables 3 and 4, in terms of adjusted $R^{2}$, the evidence clearly shows that the adjusted $R^{2}$ are at moderate levels for the performance equations, while in the ownership equations they indicate higher explanatory power. In Table 3 the system adjusted $R^{2}$ are $17.98 \%$ and $42.28 \%$, respectively for the performance and board shareholding equations, while in Table 4 the adjusted $R^{2}$ are $21.96 \%$ and $50.94 \%$, respectively for the performance and board shareholding equations. Comparing similar studies in the literature, the adjusted $R^{2}$ in both models are quite satisfactory. As stated earlier, simple/approximate Tobin's Q in natural log-form is used as a performance indicator, but the findings remain unchanged using Tobin's $Q$ without the natural log transformation. ${ }^{7}$ The models do not include any variable such as firm-specific industry dummy or year dummy for any fixed-effects, such as fixed-industry effects (between firm variations) or fixed-firm effects (within firm variations). Although, a few studies in the literature that use the simultaneous equations approach include selected industry dummies in the models, none include year dummies.

\footnotetext{
${ }^{7}$ For brevity these results are not reported here but are available from the authors upon request.
} 
However, by running 2-SLS regressions including industry dummies we find that the degree of significance of the parameter estimates and $R^{2}$ are close to those obtained for the original performance and board ownership equations and thus no significant industry-effect can be observed in the performance equations, ${ }^{8}$

The main 2-SLS regression finding that board ownership has no impact on firm performance but that performance has an impact on board ownership suggest that board members do not enjoy decision authority due to the presence of dominant family owner or government. Board ownership is one part of a large set of governance control mechanisms applied by the firm to reduce agency costs but there are many other alternative mechanisms to resolve agency conflicts as found in this study. So, it is plausible that rather than board ownership, other governance mechanisms such as institutional shareholdings, board salary, dividend, leverage and Big-4 audit firm enhance firm performance in Bangladesh listed firms.

\section{Conclusion}

This paper extends the existing literature on the relationship between board ownership and firm performance to an emerging market economy setting, Bangladesh. There are enormous institutional differences between the corporate governance mechanisms of developed and emerging economies. An analysis of Bangladesh governance systems and the institutional setting suggests that it significantly lags behind developed economies in respect of competitive markets, updating and strengthening the legal, judicial and tax systems, enforcing financial discipline, fostering well-regulated securities markets and building professional capacity and transparency as external sources of discipline/control for the corporate sector. However, despite these differences in governance systems, the empirical results of this paper using a simultaneous equations model confirm the general findings for the US and other developed countries that there is a reverse-causality between board ownership and financial performance. The other findings of this study are generally consistent with the implications of agency theory and internal sources of discipline/control.

Higher firm performance encourages board members to reduce their holdings and vice versa. A plausible explanation for liquidating part of their stockholdings is to recoup a capital gain as they overcome the problem of having lack of diversification in their their human capital. Furthermore, having an inverse relationship between board ownership and institutional ownership and a U-shaped non-linear relationship between institutional shareholding and firm performance suggest that the monitoring role of institutional investors has value in enhancing performance upon acquiring a substantial proportion of firm equity. That means, as board ownership goes down with performance, institutional ownership creeps up at the same time to fill the gap as part of total firmlevel incentive mechanisms to support and sustain improved performance.

From estimates of the performance equation, our findings support both the incentive alignment and entrenchment effect of board salary on performance with a non-linear

\footnotetext{
${ }^{8}$ For brevity these results are not reported here but are available from the authors upon request.
} 
relationship. They also support the need for prudent financial policy (debt, DPS) and accounting and auditing quality (Big-4 affiliated audit firm) for firms to enhance their performance. We document that there exists little difference between the executing and controlling authority (management vs board) of the firm. While non-executive directors have no influence on performance, owner CEO has a positive performance effect but higher CEO tenure impacts negatively on firm performance. The discretionary expenditures (investment and advertising expenditure ratio) have a positive impact on performance, while firm-specific risk (earnings volatility) has a negative impact. From estimates of the board ownership equation, our findings suggest that CEO tenure, CEOchairman duality and board size enhance board ownership. Other factors including debt, liquidity and firm risk (profit volatility) are associated with increased board ownership. Firm age, firm size and investment ratio are found to have a negative impact on board ownership.

\section{References}

Agrawal, A. and C. R. Knoeber, 1996, "Firm Performance and Mechanisms to Control Agency Problems between Managers and Shareholders," Journal of Financial and Quantitative Analysis 31, 377-397.

Berle, A. and G. Means, 1932, Modern Corporation and Private Property, (Macmillan, New York: World INC.).

Bohren, O. and B. A. Odegaard, 2001, "Corporate Governance and Economic Performance in Norwegian Listed Firms", Research Report 11, Norwegian School of Management.

Chen, H., J. L. Hexter and M. Y. Hu, 1993, "Management Ownership and Corporate Value", Managerial and Decision Economics 14, 335-346.

Cho, M. H., 1998, "Ownership Structure, Investment and the Corporate Value: An Empirical Analysis”, Journal of Financial Economics 47, 103-121.

Chung, K. and S. Pruitt, 1994, “A Simple Approximation of Tobin's Q", Financial Management 23, 70-74.

Chung, K. and S. Pruitt, 1996, "Executive Ownership, Corporate Value, and Executive Compensation: A Unifying Framework", Journal of Banking and Finance 20, 1135 -1159 .

Demsetz, H., 1983, "The Structure of Ownership and the Theory of the Firm”, Journal of Law and Economics 26, 375-390.

Demsetz, H. and K. Lehn, 1985, "The Structure of Corporate Ownership: Causes and Consequences", Journal of Political Economy 93, 1155-1177.

Demsetz, H. and B. Villalonga, 2001, “Ownership Structure and Corporate Performance", Journal of Corporate Finance 7, 209-233.

Fama, E. F. and M. Jensen, 1983a, "Separation of Ownership and Control", Journal of Law and Economics 26, 301-325.

Fama, E. F. and M. Jensen, 1983b, “Agency Problems and Residual Claims”, Journal of Law and Economics 26, 327-374. 
Fernandez, C. and S. Gomez, 2002, "Does Ownership Structure Affect Firm Performance? Evidence From a Continental-type Governance System”, Working paper.

Firth, M., P. M. Y. Fung, and O. M. Rui, 2002, "Simultaneous Relationships Among Ownership, Corporate Governance and Financial Performance", Working paper.

Hart, O. D. and B. Holmstrom, 1987, "The Theory of Contracts", in: T. Bewley (eds), Advances of Economic Theory, Fifth World Congress (Cambridge University Press).

Jensen, M. and W. Meckling, 1976, "Theory of the Firm; Managerial Behaviour, Agency Costs and Ownership Structure", Journal of Financial Economics 3, 305-360.

Jensen, M., 1986, “Agency Costs of Free Cash Flow, Corporate Finance and Takeovers", American Economic Review 76, 323-329.

Kole, S. R., 1996, "Managerial Ownership and Firm Performance: Incentives or Rewards?", Advances in Financial Economics 2, 119-149.

Kole, S. R. and K. Lehn, 1997, "Deregulation, the Evaluation of Governance Structure and Survival", American Economic Review, Papers and Proceedings 87, 421-425.

La Porta, R., F. Lopez-de-Silanes, A. Shleifer, and R. Vishny, 1998, "Law and Finance", Journal of Political Economy 106, 1113-1155.

La Porta, R., F. Lopez-de-Silanes, and A. Shleifer, 1999, “Corporate Ownership around the World", Journal of Finance LIV, 471-517.

Lichtenberg, F. and G. M. Pushner, 1994, "Ownership Structure and Corporate Performance in Japan”, Japan and the World Economy, Elsevier 6, 239-261.

Linderberg, E. and S. Ross, 1981, “Tobin's Q Ratio and Industrial Organization”, Journal of Business 54, 1-32,

Loderer, C. and K. Martin, 1997, "Executive Stock Ownership and Performance: Tracking Faint Traces", Journal of Financial Economics 45, 223-255.

McConnell, J. J. and H. Servaes, 1990, “Additional Evidence on Equity Ownership and Corporate Value”, Journal of Financial Economics 27, 595-612.

McConnell, J. J. and H. Servaes, 1995, "Equity Ownership and the Two Faces of Debt", Journal of Financial Economics 39, 131-157.

Mckinsey and Company, 2001, "Emerging Market Investor Opinion Survey 2001", Directorship, 4-8.

Mehran, H., 1995, "Executive Compensation Structure, Ownership and Firm Performance", Journal of Financial Economics 38, 163-184.

Morck, R., A. Shleifer, and R. Vishny, 1988, "Management Ownership and Market Valuation", Journal of Financial Economics 20, 293-315.

Prowse, S., 1999, "Corporate Governance in East Asia: A Framework for Analysis", Paper presented at high level Seminar on Managing Capital Flows, Bangkok, 15-16 June, 1998, Organized by ADB, IMF, WB and United Nations Economic and Social Commission for Asia and the Pacific.

Shleifer, A. and R. W. Vishny, 1986, "Large Shareholders and Corporate Control", Journal of Political Economy 94, 461-488.

Shleifer, A. and R. W. Vishny, 1997, “A survey of Corporate Governance”, Journal of Finance LII, 737-783. 
Short, H. and K. Keasey, 1999, "Managerial Ownership and the Performance of Firms: Evidence From the UK", Journal of Corporate Finance 5, 79-101.

Smith, C. W., Jr. and R. L. Watts, 1992, "The Investment Opportunity Set and Corporate Financing, Dividend and Compensation Policies", Journal of Financial Economics 32, 263-292.

World Bank, 1999, Corporate Governance: A Framework for Implementation, (Washington). 


\section{Appendix 1}

Figure 1: Variable Definition

Performance Equation: (TOBIN'S Q or ROA as predicted variable)

\begin{tabular}{|c|c|c|c|}
\hline Variable label & Variable & Variable definition & Predicted sign \\
\hline \multicolumn{4}{|l|}{$\begin{array}{l}\text { Endogenous } \\
\text { variable: }\end{array}$} \\
\hline BD-SHARE & Board ownership & $\begin{array}{l}\text { Board shareholding as a } \% \text { of } \\
\text { total outstanding shares }\end{array}$ & $+/-$ \\
\hline \multicolumn{4}{|l|}{$\begin{array}{l}\text { Explanatory } \\
\text { variables: }\end{array}$} \\
\hline BD-SAL1 & Board salary (Spline -1$)$ & Tk $00-0.15$ million & $+/-$ \\
\hline BD-SAL2 & Board salary (Spline - 2) & Tk 0.15 million- 0.75 million & $+/-$ \\
\hline BD-SAL3 & Board salary (Spline -3 ) & Above Tk 0.75 million & $+/-$ \\
\hline INST-SHARE & $\begin{array}{c}\text { Financial institutional } \\
\text { ownership }\end{array}$ & $\begin{array}{l}\text { Institutional shareholding as a } \\
\% \text { of total outstanding shares }\end{array}$ & $+/-$ \\
\hline$(\text { INST-SHARE })^{2}$ & Institutions ownership squared & & $+/-$ \\
\hline $\begin{array}{l}\text { NON-EXE-DIR- } \\
\text { Ratio }\end{array}$ & Non-executive directors' ratio & $\begin{array}{l}\text { Ratio of non-executive } \\
\text { directors } \div \text { all directors }\end{array}$ & + \\
\hline CEO-DUM & CEO dummy & $\begin{array}{l}\text { Owner or founder acts as } \\
\text { CEO }=1\end{array}$ & - \\
\hline CEO-CHAIR-DUM & CEO-Chair duality dummy & $\mathrm{CEO}$ acts as Chairman $=1$ & - \\
\hline CEO-TENURE & CEO tenure & No. of years served as CEO & - \\
\hline DPS & Dividend per share & $\begin{array}{l}\text { Total dividend declared } \div \\
\text { total outstanding shares }\end{array}$ & + \\
\hline $\begin{array}{l}\text { BIG-4 AUDIT- } \\
\text { DUM }\end{array}$ & BIG-4 affiliated dummy & $\begin{array}{c}\text { BIG-4 affiliated audit firm }= \\
1\end{array}$ & + \\
\hline DEBT-Ratio & Debt ratio & Debt $\div$ total assets & - \\
\hline LOG-SALES & Firm size & Log total sales & - \\
\hline INVEST-Ratio & Investment ratio & $\begin{array}{l}\text { Capital expenditure } \div \\
\text { total assets }\end{array}$ & + \\
\hline ADVER-Ratio & Advertising ratio & $\begin{array}{l}\text { Advertising expenditure } \div \\
\text { total assets }\end{array}$ & + \\
\hline EARN-VOLATILE & Firm-level risk & $\begin{array}{l}\text { SD of operating earnings } \div \\
\text { total sales }\end{array}$ & - \\
\hline
\end{tabular}


Ownership Equation: (BD-SHARE as predicted variable)

\begin{tabular}{|c|c|c|c|}
\hline Variable label & Variable & Variable definition & Predicted sign \\
\hline \multicolumn{4}{|l|}{$\begin{array}{l}\text { Endogenous } \\
\text { variable: }\end{array}$} \\
\hline TOBIN'S-Q & Proxy for Tobin’s Q (simple) & $\begin{array}{l}\text { (Market value of equity plus } \\
\text { book value of debt) } \div \text { book } \\
\text { value of total assets }\end{array}$ & $+/-$ \\
\hline Or & & & \\
\hline ROA & Return on assets & $\begin{array}{c}\text { EBIT } \div \text { book value of total } \\
\text { assets }\end{array}$ & $+/-$ \\
\hline \multicolumn{4}{|l|}{$\begin{array}{l}\text { Explanatory } \\
\text { variables: }\end{array}$} \\
\hline INST-SHARE & $\begin{array}{c}\text { Financial institutional } \\
\text { ownership }\end{array}$ & $\begin{array}{l}\text { Institutional shareholding as a } \\
\% \text { of total outstanding shares }\end{array}$ & - \\
\hline PUB-SHARE & Public ownership & $\begin{array}{c}\text { Minority shareholding as a } \% \\
\text { of total outstanding shares }\end{array}$ & - \\
\hline GOV-SHARE & Government ownership & $\begin{array}{l}\text { Government shareholding as a } \\
\% \text { of total outstanding shares }\end{array}$ & - \\
\hline BD-SIZE & Board size & $\begin{array}{c}\text { Number of directors on the } \\
\text { board }\end{array}$ & + \\
\hline BD-SAL-Ratio & Board salary ratio & $\begin{array}{l}\text { Directors' salary } \div \\
\text { operating expense }\end{array}$ & - \\
\hline CEO-CHAIR-DUM & CEO-Chair duality dummy & $\mathrm{CEO}$ acts as Chairman $=1$ & + \\
\hline CEO-TENURE & CEO tenure & No. of years served as CEO & + \\
\hline FIRM-AGE & Firm age & $\begin{array}{l}\text { No. of years incorporated as a } \\
\text { public limited company }\end{array}$ & - \\
\hline DEBT-Ratio & Debt ratio & Debt $\div$ total assets & + \\
\hline LOG-ASSETS & Firm size & Log total assets & - \\
\hline INVEST-Ratio & Investment ratio & $\begin{array}{l}\text { Capital expenditure } \div \\
\text { total assets }\end{array}$ & + \\
\hline $\begin{array}{l}\text { PROFIT- } \\
\text { VOLATILE }\end{array}$ & Firm-level risk & SD of return on equity (ROE) & + \\
\hline LIQUIDITY-Ratio & Liquidity ratio & Cash flow $\div$ total assets & + \\
\hline
\end{tabular}




\section{Appendix 2}

Table 1: Summary Statistics on Governance and Financial Characteristics

\begin{tabular}{|c|c|c|c|c|c|}
\hline Variable & Mean & Median & S.D. & Minimum & Maximum \\
\hline TOBIN'S Q & 1.157 & 0.989 & 0.714 & 0.07 & 7.46 \\
\hline ROA & 0.081 & 0.080 & 0.066 & -0.45 & 0.36 \\
\hline BD-SHARE & 0.387 & 0.477 & 0.195 & 0.00 & 0.982 \\
\hline BD-SAL (Tk mill.) & 0.912 & 0.420 & 1.461 & 0.00 & 11.41 \\
\hline BD-SAL-Ratio & 0.043 & 0.021 & 0.060 & 0.00 & 0.33 \\
\hline BD-SIZE & 8.3 & 6.0 & 6.144 & 3 & 37 \\
\hline NON-EXE-DIR-Ratio & 0.673 & 0.80 & 0.292 & 0.00 & 0.97 \\
\hline INST-SHARE & 0.183 & 0.169 & 0.111 & 0.001 & 0.581 \\
\hline PUB-SHARE & 0.307 & 0.306 & 0.151 & 0.009 & 0.788 \\
\hline GOV-SHARE & 0.028 & 0.00 & 0.112 & 0.00 & 0.66 \\
\hline CEO-DUM (no. of cases) & $515=78 \% *$ & & & & \\
\hline CEO-TENURE & 10.4 & 9.0 & 7.183 & 1 & 31 \\
\hline $\begin{array}{l}\text { CEO-CHAIR-DUM } \\
\text { (no. of cases) }\end{array}$ & $263=40 \% *$ & & & & \\
\hline EPS (Tk.) & 22.3 & 11.32 & 53.40 & -152.71 & 657.37 \\
\hline DPS (Tk.) & 8.9 & 4.75 & 11.672 & 0.00 & 100.34 \\
\hline FIRM-AGE & 14.8 & 14 & 8.17 & 1 & 43 \\
\hline $\begin{array}{l}\text { BIG-4 AUDIT-DUM } \\
\text { (no. of cases) }\end{array}$ & $224=34 \% *$ & & & & \\
\hline DEBT (Tk. mill.) & 779.6 & 241.5 & 2622.15 & 1.20 & 35242.74 \\
\hline DEBT-Ratio & 0.572 & 0.587 & 0.216 & 0.01 & 1.00 \\
\hline INVEST (Tk. mill.) & 39.0 & 6.6 & 149.28 & 0.00 & 2724.97 \\
\hline INVEST-Ratio & 0.053 & 0.017 & 0.010 & 0.00 & 0.87 \\
\hline ADVER (Tk. mill.) & 3.2 & 0.4 & 14.52 & 0.00 & 199.58 \\
\hline ADVER-Ratio & 0.005 & 0.001 & 0.018 & 0.00 & 0.20 \\
\hline CASH FLOW (Tk. mill.) & 49.5 & 24.3 & 86.54 & -95.71 & 701.81 \\
\hline LIQUIDITY-Ratio & 0.066 & 0.06 & 0.07 & -0.41 & 0.65 \\
\hline Firm size - SALES (Tk. mill.) & 585.5 & 245.1 & 1673.52 & 1.17 & 20010.11 \\
\hline Firm size - ASSETS (Tk. mill.) & 1079.2 & 399.1 & 2767.19 & 9.00 & 36370.94 \\
\hline $\begin{array}{l}\text { Firm-level risk } \\
\text { (EARN-VOLATILE) }\end{array}$ & 0.092 & 0.016 & 0.93 & 0.00 & 22.55 \\
\hline $\begin{array}{l}\text { Firm-level risk } \\
\text { (PROFIT-VOLATILE) }\end{array}$ & 0.149 & 0.015 & 1.716 & 0.00 & 35.42 \\
\hline
\end{tabular}

* percentage of the sample size. 
Table 3: Determinants of Tobin's Q and Board Ownership

\begin{tabular}{|c|c|c|c|c|}
\hline Variables & $\begin{array}{c}\text { Log Tobin's } \\
\text { Q } \\
\text { (OLS) }\end{array}$ & $\begin{array}{c}\text { Log Tobin's } \\
\text { Q } \\
\text { (2SLS) }\end{array}$ & $\begin{array}{c}\text { Board } \\
\text { Ownership } \\
(\text { OLS })\end{array}$ & $\begin{array}{c}\text { Board } \\
\text { Ownership } \\
\text { (2SLS) }\end{array}$ \\
\hline CONSTANT & $\begin{array}{l}-0.055 \\
(-1.055)\end{array}$ & $\begin{array}{l}-0.076 \\
(-1.367)\end{array}$ & $\begin{array}{l}0.724 \\
(17.418) * * *\end{array}$ & $\begin{array}{l}0.702 \\
(13.010) * * *\end{array}$ \\
\hline BD-SHARE & $\begin{array}{l}-0.116 \\
(-2.722)^{* * * *}\end{array}$ & $\begin{array}{l}-0.054 \\
(-0.796)\end{array}$ & & \\
\hline LOG TOBIN'S-Q & & & $\begin{array}{l}-0.172 \\
(-5.306) * * *\end{array}$ & $\begin{array}{l}-0.846 \\
(-6.538) * * *\end{array}$ \\
\hline INST-SHARE & $\begin{array}{l}-0.588 \\
(-3.014)^{* * * *}\end{array}$ & $\begin{array}{l}-0.581 \\
(-2.972) * * *\end{array}$ & $\begin{array}{l}-0.531 \\
(-10.411)^{* * *}\end{array}$ & $\begin{array}{l}-0.624 \\
(-9.160) * * *\end{array}$ \\
\hline$(\text { INST-SHARE) })^{2}$ & $\begin{array}{l}0.934 \\
(2.224)^{* *}\end{array}$ & $\begin{array}{l}0.974 \\
(2.308) * *\end{array}$ & & \\
\hline PUB-SHARE & & & $\begin{array}{l}-0.356 \\
(-9.241) * * *\end{array}$ & $\begin{array}{l}-0.414 \\
(-8.120) * * *\end{array}$ \\
\hline GOV-SHARE & & & $\begin{array}{l}-0.448 \\
(-8.202)^{* * *}\end{array}$ & $\begin{array}{l}-0.521 \\
(-7.246) * * *\end{array}$ \\
\hline BD-SIZE & & & $\begin{array}{l}0.004 \\
(4.046) * * *\end{array}$ & $\begin{array}{l}0.003 \\
(2.355)^{* *}\end{array}$ \\
\hline NON-EXE-DIR-Ratio & $\begin{array}{l}0.011 \\
(0.428)\end{array}$ & $\begin{array}{l}0.008 \\
(0.306)\end{array}$ & & \\
\hline $\begin{array}{l}\text { BD-SAL1 } \\
\text { (up to Tk } 0.15 \mathrm{~m} \text { ) }\end{array}$ & $\begin{array}{l}0.564 \\
(3.381)^{* * * *}\end{array}$ & $\begin{array}{l}0.559 \\
(3.339) * * *\end{array}$ & & \\
\hline $\begin{array}{l}\text { BD-SAL2 } \\
(\mathrm{Tk} 0.15-0.75 \mathrm{~m})\end{array}$ & $\begin{array}{l}-0.096 \\
(-2.310)^{*} *\end{array}$ & $\begin{array}{l}-0.087 \\
(-2.071)^{* *}\end{array}$ & & \\
\hline $\begin{array}{l}\text { BD-SAL3 } \\
\text { (over Tk } 0.75 \mathrm{~m})\end{array}$ & $\begin{array}{l}0.019 \\
(2.929) * * *\end{array}$ & $\begin{array}{l}0.021 \\
(3.091)^{* * *}\end{array}$ & & \\
\hline BD-SAL-Ratio & & & $\begin{array}{l}-0.436 \\
(-4.523) * * *\end{array}$ & $\begin{array}{l}-0.112 \\
(-0.810)\end{array}$ \\
\hline CEO-DUM & $\begin{array}{l}0.063 \\
(2.877)^{* * * *}\end{array}$ & $\begin{array}{l}0.057 \\
(2.541)^{* * *}\end{array}$ & & \\
\hline CEO-CHAIR-DUM & $\begin{array}{l}0.013 \\
(0.829)\end{array}$ & $\begin{array}{l}0.009 \\
(0.540)\end{array}$ & $\begin{array}{l}0.068 \\
(5.619) * * *\end{array}$ & $\begin{array}{l}0.062 \\
(3.953)^{* * *} *\end{array}$ \\
\hline CEO-TENURE & $\begin{array}{l}-0.003 \\
(-2.888) * * *\end{array}$ & $\begin{array}{l}-0.003 \\
(-3.018) * * *\end{array}$ & $\begin{array}{l}0.007 \\
(7.392)^{* * * *}\end{array}$ & $\begin{array}{l}0.003 \\
(2.238)^{* *}\end{array}$ \\
\hline FIRM-AGE & & & $\begin{array}{l}-0.007 \\
(-8.817)^{* * *}\end{array}$ & $\begin{array}{l}-0.004 \\
(-3.451) * * *\end{array}$ \\
\hline DPS & $\begin{array}{l}0.002 \\
(3.796) * * *\end{array}$ & $\begin{array}{l}0.002 \\
(3.660) * * *\end{array}$ & & \\
\hline BIG-4 AUDIT-DUM & $\begin{array}{l}0.064 \\
(4.092) * * *\end{array}$ & $\begin{array}{l}0.067 \\
(4.234) * * *\end{array}$ & & \\
\hline DEBT-Ratio & $\begin{array}{l}0.167 \\
(4.888) * * *\end{array}$ & $\begin{array}{l}0.160 \\
(4.615) * * *\end{array}$ & $\begin{array}{l}0.086 \\
(2.953) * * *\end{array}$ & $\begin{array}{l}0.218 \\
(4.882)^{* * * *}\end{array}$ \\
\hline LOG-SALES & $\begin{array}{l}-0.019 \\
(-1.370)\end{array}$ & $\begin{array}{l}-0.017 \\
(-1.260)\end{array}$ & & \\
\hline
\end{tabular}




\begin{tabular}{|c|c|c|c|c|}
\hline LOG-ASSETS & & & $\begin{array}{l}-0.061 \\
(-5.416) * * *\end{array}$ & $\begin{array}{l}-0.081 \\
(-5.364) * * * *\end{array}$ \\
\hline INVEST-Ratio & $\begin{array}{l}0.147 \\
(2.108)^{* *}\end{array}$ & $\begin{array}{l}0.148 \\
(2.118) * *\end{array}$ & $\begin{array}{l}-0.109 \\
(-1.965)^{* *}\end{array}$ & $\begin{array}{l}-0.014 \\
(-0.183)\end{array}$ \\
\hline ADVER-Ratio & $\begin{array}{l}1.931 \\
(4.850)^{* * *}\end{array}$ & $\begin{array}{l}2.024 \\
(4.980)^{* * * *}\end{array}$ & & \\
\hline EARN-VOLATILE & $\begin{array}{l}-0.008 \\
(-1.159)\end{array}$ & $\begin{array}{l}-0.008 \\
(-1.145)\end{array}$ & & \\
\hline PROFIT-VOLATILE & & & $\begin{array}{l}0.006 \\
(2.019)^{* *}\end{array}$ & $\begin{array}{l}0.012 \\
(2.789) * * *\end{array}$ \\
\hline LIQUIDITY-Ratio & & & $\begin{array}{l}-0.166 \\
(-1.997) * *\end{array}$ & $\begin{array}{l}0.370 \\
(2.549) * * *\end{array}$ \\
\hline $\mathrm{N}$ & 660 & 660 & 660 & 660 \\
\hline Adjusted $\mathrm{R}^{2}$ & 0.187 & 0.1798 & 0.540 & 0.4228 \\
\hline F-statistic & $9.929 * * *$ & $9.499 * * *$ & $56.264 * * *$ & $35.477 * * *$ \\
\hline Turning point & & $29.83 \%$ & & \\
\hline
\end{tabular}

Table 4: Determinants of ROA and Board Ownership

\begin{tabular}{|c|c|c|c|c|}
\hline Variables & $\begin{array}{c}\text { ROA } \\
\text { (OLS) }\end{array}$ & $\begin{array}{c}\text { ROA } \\
\text { (2SLS) }\end{array}$ & $\begin{array}{c}\text { Board } \\
\text { Ownership } \\
\text { (OLS) }\end{array}$ & $\begin{array}{c}\text { Board } \\
\text { Ownership } \\
\text { (2SLS) }\end{array}$ \\
\hline CONSTANT & $\begin{array}{l}0.019 \\
(1.028)\end{array}$ & $\begin{array}{l}0.013 \\
(0.682)\end{array}$ & $\begin{array}{l}0.735 \\
(17.242)^{* * *}\end{array}$ & $\begin{array}{l}0.758 \\
(16.930)^{* * * *}\end{array}$ \\
\hline BD-SHARE & $\begin{array}{l}0.011 \\
(0.733)\end{array}$ & $\begin{array}{l}0.029 \\
(1.213)\end{array}$ & & \\
\hline ROA & & & $\begin{array}{l}-0.168 \\
(-1.157)\end{array}$ & $\begin{array}{l}-1.040 \\
(-2.720)^{* * *}\end{array}$ \\
\hline INST-SHARE & $\begin{array}{l}-0.202 \\
(-2.898)^{* * *}\end{array}$ & $\begin{array}{l}-0.120 \\
(-2.865)^{* * *}\end{array}$ & $\begin{array}{l}-0.517 \\
(-9.848) * * *\end{array}$ & $\begin{array}{l}-0.564 \\
(-9.859)^{* * *}\end{array}$ \\
\hline$(\text { INST-SHARE) })^{2}$ & $\begin{array}{l}0.444 \\
(2.961)^{* * * *}\end{array}$ & $\begin{array}{l}0.456 \\
(3.026) * * *\end{array}$ & & \\
\hline PUB-SHARE & & & $\begin{array}{l}-0.349 \\
(-8.781)^{* * *}\end{array}$ & $\begin{array}{l}-0.384 \\
(-8.885)^{* * * *}\end{array}$ \\
\hline GOV-SHARE & & & $\begin{array}{l}-0.436 \\
(-7.801)^{* * *}\end{array}$ & $\begin{array}{l}-0.474 \\
(-7.972) * * *\end{array}$ \\
\hline BD-SIZE & & & $\begin{array}{l}0.004 \\
(3.971)^{* * * *}\end{array}$ & $\begin{array}{l}0.003 \\
(2.739)^{* * * *}\end{array}$ \\
\hline NON-EXE-DIR-Ratio & $\begin{array}{l}-0.002 \\
(-0.259)\end{array}$ & $\begin{array}{l}-0.003 \\
(-0.355)\end{array}$ & & \\
\hline $\begin{array}{l}\text { BD-SAL1 } \\
\text { (up to Tk } 0.15 \mathrm{~m} \text { ) }\end{array}$ & $\begin{array}{l}0.078 \\
(1.312)\end{array}$ & $\begin{array}{l}0.077 \\
(1.282)\end{array}$ & & \\
\hline
\end{tabular}




\begin{tabular}{|c|c|c|c|c|}
\hline $\begin{array}{l}\text { BD-SAL2 } \\
\text { (Tk 0.15-0.75 m) }\end{array}$ & $\begin{array}{l}-0.039 \\
(-2.608) * * *\end{array}$ & $\begin{array}{l}-0.036 \\
(-2.404) * *\end{array}$ & & \\
\hline $\begin{array}{l}\text { BD-SAL3 } \\
\text { (over Tk } 0.75 \text { m) }\end{array}$ & $\begin{array}{l}0.007 \\
(3.145)^{* * * *}\end{array}$ & $\begin{array}{l}0.008 \\
(3.265)^{* * *}\end{array}$ & & \\
\hline BD-SAL-Ratio & & & $\begin{array}{l}-0.515 \\
(-5.302)^{* * *}\end{array}$ & $\begin{array}{l}-0.497 \\
(-4.965)^{* * *}\end{array}$ \\
\hline CEO-DUM & $\begin{array}{l}0.019 \\
(2.400)^{* *}\end{array}$ & $\begin{array}{l}0.017 \\
(2.126)^{* *}\end{array}$ & & \\
\hline CEO-CHAIR-DUM & $\begin{array}{l}-0.004 \\
(-0.786)\end{array}$ & $\begin{array}{l}-0.006 \\
(-0.982)\end{array}$ & $\begin{array}{l}0.069 \\
(5.573) * * *\end{array}$ & $\begin{array}{l}0.065 \\
(5.135)^{* * *}\end{array}$ \\
\hline CEO-TENURE & $\begin{array}{l}-0.001 \\
(-2.017)^{* *}\end{array}$ & $\begin{array}{l}-0.001 \\
(-2.127)^{* *}\end{array}$ & $\begin{array}{l}0.008 \\
(8.255)^{* * *}\end{array}$ & $\begin{array}{l}0.008 \\
(7.232)^{* * *}\end{array}$ \\
\hline FIRM-AGE & & & $\begin{array}{l}-0.008 \\
(-9.460) * * *\end{array}$ & $\begin{array}{l}-0.007 \\
(-7.876)^{* * *}\end{array}$ \\
\hline DPS & $\begin{array}{l}0.001 \\
(6.185)^{* * *}\end{array}$ & $\begin{array}{l}0.001 \\
(6.058) * * *\end{array}$ & & \\
\hline BIG-4 AUDIT-DUM & $\begin{array}{l}0.004 \\
(0.674)\end{array}$ & $\begin{array}{l}0.005 \\
(0.838)\end{array}$ & & \\
\hline DEBT-Ratio & $\begin{array}{l}-0.017 \\
(-1.414)\end{array}$ & $\begin{array}{l}-0.019 \\
(-1.554)\end{array}$ & $\begin{array}{l}0.061 \\
(2.033) * *\end{array}$ & $\begin{array}{l}0.104 \\
(2.946)^{* * *}\end{array}$ \\
\hline LOG-SALES & $\begin{array}{l}0.026 \\
(5.396)^{* * *}\end{array}$ & $\begin{array}{l}0.027 \\
(5.453) * * *\end{array}$ & & \\
\hline LOG-ASSETS & & & $\begin{array}{l}-0.056 \\
(-4.874) * * *\end{array}$ & $\begin{array}{l}-0.055 \\
(-4.643) * * *\end{array}$ \\
\hline INVEST-Ratio & $\begin{array}{l}0.036 \\
(1.447)\end{array}$ & $\begin{array}{l}0.036 \\
(1.456)\end{array}$ & $\begin{array}{l}-0.137 \\
(-2.417)^{* *}\end{array}$ & $\begin{array}{l}-0.153 \\
(-2.622) * * *\end{array}$ \\
\hline ADVER-Ratio & $\begin{array}{l}0.696 \\
(4.893) * * *\end{array}$ & $\begin{array}{l}0.723 \\
(4.982) * * *\end{array}$ & & \\
\hline EARN-VOLATILE & $\begin{array}{l}-0.010 \\
(-3.758) * * *\end{array}$ & $\begin{array}{l}-0.010 \\
(-3.745)^{* * *}\end{array}$ & & \\
\hline PROFIT-VOLATILE & & & $\begin{array}{l}0.005 \\
(1.527)\end{array}$ & $\begin{array}{l}0.004 \\
(1.310)\end{array}$ \\
\hline LIQUIDITY-Ratio & & & $\begin{array}{l}-0.170 \\
(-1.205)\end{array}$ & $\begin{array}{l}0.520 \\
(1.657)^{*}\end{array}$ \\
\hline $\mathrm{N}$ & 660 & 660 & 660 & 660 \\
\hline Adjusted $\mathrm{R}^{2}$ & 0.219 & 0.2196 & 0.521 & 0.5094 \\
\hline F-statistic & $11.877 * * *$ & $11.906^{* * *}$ & $52.188 * * *$ & $49.882 * * *$ \\
\hline Turning point & & $13.16 \%$ & & \\
\hline
\end{tabular}

*** Significance at $1 \%$ confidence level using two-tailed test.

** Significance at 5\% confidence level using two-tailed test.

* Significance at $10 \%$ confidence level using two-tailed test. 